\title{
SEMPROTAN AIR PADA PIPA TEGAK MEMPENGARUHI DEBIT PEMBILASAN PADA MODEL "SEA-OUTFALL"
}

\author{
Sunaryo ${ }^{1}$
}

\begin{abstract}
ABSTRAK
Untuk meningkatkan pengoperasian suatu 'sea-outfall' perlu dihilangkan semua hambatan yang terjadi, seperti adanya air laut, tumbuhan laut, dan lumpur yang masuk kedalamnya yang dapat mengakibatkan terjadinya pengurangan debit air buangan yang akan dialirkan ke laut. Selain itu lama-kelamaan akan mengakibatkan kerusakan pada 'sea-outfall' itu sendiri. Untuk menghilangkan hambatan tersebut dan debit air buangan yang tetap, diperlukan suatu sistem. Dalam penelitian ini dilakukan pembuatan model 'sea-outfall' dengan meletakkan suatu penyemprotan air di bawah pipa tegak dimana air buangan akan dikeluarkan. Dari percobaan ini diperoleh debit pembilasan sebesar 36,34 liter/menit (48\%) dibandingkan tanpa semprotan air untuk beda jenis yang sama.
\end{abstract}

Kata Kunci : semprotan air, pipa tegak, debit air pembuangan, 'sea-outfall'.

\section{PENDAHULUAN}

Air kotor atau air buangan yang berasal dari daerah industri/perumahan atau suatu penjernihan air, dibuang langsung ke laut melalui suatu sistim yang disebut dengan 'sea-outfall'. Air kotor/ air buangan tersebut akan masuk ke dalam laut dan bercampur dengan air laut sejak di ujung pipa hingga suatu kedalaman dimana berat jenisnya sama dengan air laut di sekitarnya atau ke permukaan air laut. Disamping itu, air buangan tersebut akan menyebar ke samping dan menjauh dari ujung pipa.

Ukuran dari 'sea-outfall' ini tergantung kepada besarnya debit kekotoran dari air kotor yang akan dibuang. Untuk debit yang kecil, cukup dibuat 'sea-outfall' yang sederhana yang terdiri dari suatu pipa yang panjang dengan lubang pada ujungnya. Sedangkan untuk debit yang besar, air kotor dialirkan melalui suatu 'sea-outfall' dengan banyak pipa tegak berlubang pada ujungnya untuk meningkatkan pencampuran dengan air laut.

Jika 'sea-outfall' yang telah ada tidak bekerja sesuai dengan perencanaan yang diharapkan, Bennet (1981), Munro (1981) dan Charlton (1982), telah menyatakan bahwa suatu pengurangan debit air kotor disebabkan adanya intrusi air laut kedalam 'sea-outfall'. Besarnya intrusi laut telah diteliti di laboratorium (Charlton 1982,Wilkinson 1985) dan bagaimana membilas air laut dari 'sea-outfall' (Wilkinson 1984,Charlton et al. 1987, Adams et al. 1994).

Percobaan ini bertujuan untuk melakukan pembilasan air laut yang ada dalam 'sea-outfall' dengan cara mudah dan murah. Cara tersebut adalah dengan menyemprotkan air melalui suatu pipa kecil yang diletakkan dibawah pipa tegak dengan debit tertentu.

\footnotetext{
${ }^{1}$ Staf Pengajar Jurusan Teknik Sipil Fakultas Teknik Universitas Andalas
} 


\section{INTRUSI AIR LAUT DAN PEMBILASAN DALAM 'SEA-OUTFALL'}

\subsection{Intrusi Air Laut}

Air laut bisa masuk kedalam suatu 'sea-outfall' disebabkan oleh menurunnya aliran air kotor kedalam 'sea-outfall' tersebut. Pengurangan debit air kotor ini mencapai suatu titik dimana alat air laut masuk kedalam lubang dan pada saat selesainya pelaksanaan konstruksi 'sea-outfall' (Wood et al., 1993).

Charlton (1987), menyatakan bahwa intrusi air laut menjadi melalui 2 (dua) fase, yaitu fase pertama dan fase kedua. Intrusi fase pertama adalah proses intrusi air laut ketika berat jenis air kotor bertemu dan mengalir di atas air laut yang memiliki berat jenis lebih besar. Ini berhubungan dengan Bilangan Densimetric Froude $\left(F_{\Delta}\right)$ pada lubang adalah lebih rendah daripada satu $\left(F_{\Delta}<1\right)$. Intrusi fase kedua terjadi ketika debit air kotor turun ke suatu harga dimana air laut mengalir masuk kedalam lubang pada sistem.

Bilangan Densimetric Froude $\left(F_{\Delta}\right)$ pada lubang diberikan pada persamaan berikut :

$$
F_{\Delta}=\frac{U_{o}}{\sqrt{\Delta g d}}
$$

\subsection{Pembilasan}

Suatu 'sea-outfall' biasanya dipenuhi oleh air laut setelah selesai dibangun dan sebelum air kotor dialirkan kedalam 'sea-outfall' tersebut. Disamping itu, air laut yang berat jenisnya lebih besar selalu masuk ke dalam 'sea-outfall' melalui lubang untuk menggantikan air kotor didalam pipa ketika debit air kotor turun. Adanya air laut bisa mengurangi efisiensi hidrolis dari 'sea-outfall' (Bennet 1981, Munro 1981dan Charlton 1982).

Air laut dalam pipa membentuk suatu kumpulan air laut yang bisa menahan debit air kotor dari lubang yang terletak pada sebelah hilir pada kumpulan air laut tersebut (Gambar 1.b). Intrusi air laut ke dalam pipa bisa terjadi melalui beberapa lubang. Ini akan bercampur dengan air kotor dalam pipa dan mengalir kembali melalui lubang. Perputaran ini disebut sirkulasi air laut (Gambar 1.a dan Gambar 1.c). Kedua proses dari intrusi air laut bisa mengurangi debit air kotor.

Proses pembilasan dalam suatu 'sea-outfall' bisa dijelaskan dengan menggunakan Gambar 1. Debit air kotor meningkat perlahan dari nol melalui pipa lepas dari lubang pertama. Setelah debit air kotor meningkat, terjadi penahanan oleh adanya perputaran air laut (Gambar 1.a). Aliran campuran air kotor dengan air laut dalam lubang pertama turun ke dalam 'sea-outfall' melalui lubang sebelah hilir. Proses ini terjadi terus-menerus sehingga debit air kotor meningkat sampai pada suatu aliran kritis ketika tidak ada perputaran air laut dalam 'sea-outfall' (Gambar 1.b). Sesudah itu, proses pembilasan bergerak ke lubang kedua. Penahanan perputaran air laut terjadi antara lubang kedua dan lubang di hilirnya (Gambar 1.c). Pembilasan yang lengkap terjadi ketika debit air kotor melalui semua lubang (Gambar 1.d). Proses perputaran air laut dan penahan oleh air laut dalam 'sea-outfall' tersebut dijelaskan oleh Wilkinson $(1984,1985)$.

Wilkinson (1985), menurunkan suatu persamaan tak berdimensi dalam bagian suatu Bilangan Foude. Persamaan tersebut dituliskan sebagai berikut :

$$
F_{c}=\left(\frac{2}{1+\Psi}\right)^{1 / 2}
$$

yang mana,

$$
F_{c}=\frac{Q_{c}}{a(\Delta g h)^{1 / 2}}
$$


Wilkinson (1998) merekomendasikan debit air kotor untuk membilas air laut pada diameter pipa yang seragam sebagai :

$$
Q_{p}=\left(\frac{2 D\left(\frac{\Delta \rho}{\rho}\right) g \sin \theta}{f}\right) \frac{\pi D^{2}}{4}
$$
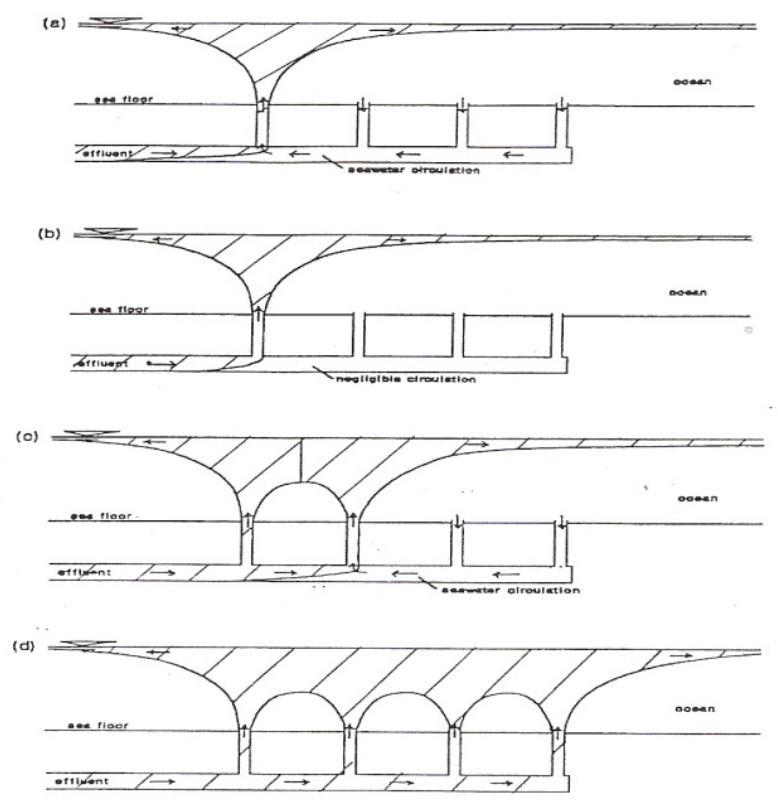

Gambar 1. Debit Air Kotor dari 'Sea-Outfall' pada Bermacam Tingkat Pembilasan.

\section{MODEL 'SEA-OUTFALL'}

\subsection{Fasilitas Percobaan}

Percobaan ini dilakukan dengan menggunakan beberapa fasilitas utama, yaitu tangki air, pipa tembus pandang, pompa air, tangki silinder dan flowmeter. Semua fasilitas ini bisa dilihat pada Gambar 2 dan Gambar 3.

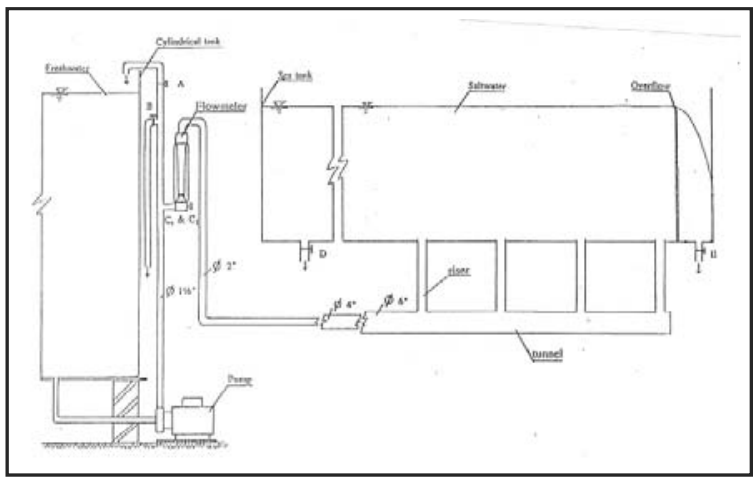

Gambar 2. Fasilitas Percobaan 
Tangki air memiliki ukuran $8500 \mathrm{~mm}$ panjang, $1000 \mathrm{~mm}$ lebar dan $1000 \mathrm{~mm}$ dalam. Salah satu bagian dari tangki tersebut dipasang kaca dengan usuran $3400 \mathrm{~mm} \times 850 \mathrm{~mm}$, sehingga semua proses penelitian bisa dilihat. Tangki air ini ditopang oleh struktur baja dan dihubungkan dengan flowmeter dan tempat penyedian air laut dengan ukuran $1220 \mathrm{~mm} \times 570 \mathrm{~mm}$.

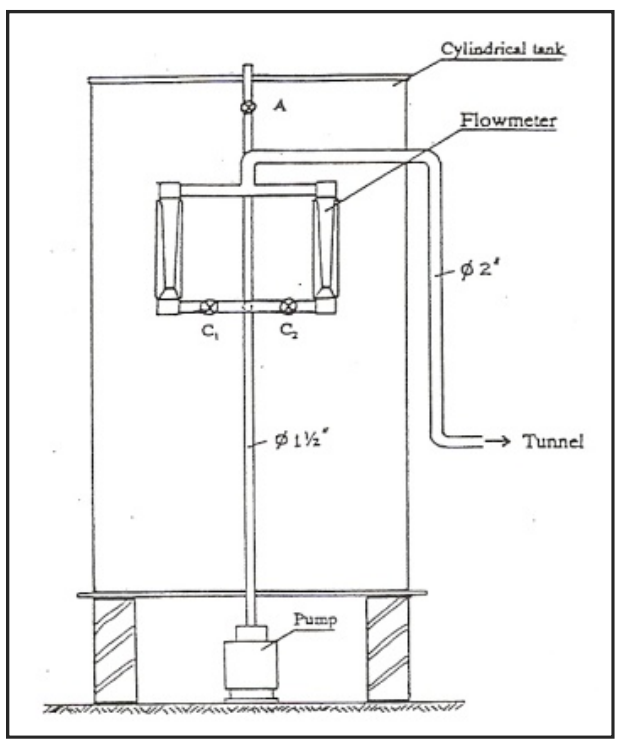

Gambar 3. Fasilitas Tangki Silinder

Model dari 'sea-outfall' diletakkan di bawah tangki air dan dihubungkan dengan dasar tangki air tersebut dengan empat buah pipa tegak. Dasar tangki air menunjukkan sebagai dasar laut. Diameter dalam dari pipa datar dan pipa tegak, masing-masing adalah $146 \mathrm{~mm}$ dan $57 \mathrm{~mm}$. Pipa datar dan pipa tegak dibuat dari pipa plastik yang bening agar mudah dilihat proses dari penelitian. Pipa datar dihubungkan dengan pompa dan tangki silinder dengan PVC.

\subsection{Prosedur Percobaan}

Percobaan pembilasan dilakukan dengan menggunakan fasilitas yang ada pada Gambar 1 dengan mengidentifikasi proses bercampurnya air bersih (sebagai air kotor) dengan air asin (sebagai air laut) dan berkembangnya sirkulasi penghambatan yang akhirnya terjadi pembilasan.

Pembilasan dilakukan dengan menggunakan variasi gabungan dari debit air bersih di dalam pipa utama yang merupakan aliran air kotor, variasi berat jenis air asin dalam tangki silinder yang merupakan air laut dan meletakkan semprotan air di bawah keempat pipa tegak dengan diameter 2 $\mathrm{mm}$.

Untuk memudahkan penglihatan dalam percampuran antara air asin dengan air bersih, zat warna dicampur dengan air bersih dalam tangki silinder dengan menggunakan pompa. Zat warna yang digunakan adalah 07209 Amaranth Supra yang diproduksi oleh Warner Jenkinson Limited..

Debit air bersih yang digunakan dalam percobaan berkisar anatar 11,36 liter/menit sampai dengan 68,14 liter/menit. Berat jenis air asin dalam tangki silinder adalah $1,010 \mathrm{gr} / \mathrm{cm}^{3}$.

Semprotan air diletakkan pada bagian bawah semua pipa tegak dalam pipa utama untuk meningkatkan percampuran antara air bersih dengan air asin (Gambar 4 dan Gambar 5). Diameter dari pipa kecil adalah $2 \mathrm{~mm}\left(0,1\right.$ inci). Pipa kecil dihubungkan dengan flowmeter dan kran $\mathrm{H}_{1}, \mathrm{H}_{2}$, $\mathrm{H}_{3}$, dan $\mathrm{H}_{4}$ (Gambar 4 dan Gambar 5). Debit air ini adalah sebesar 1 liter/menit. 


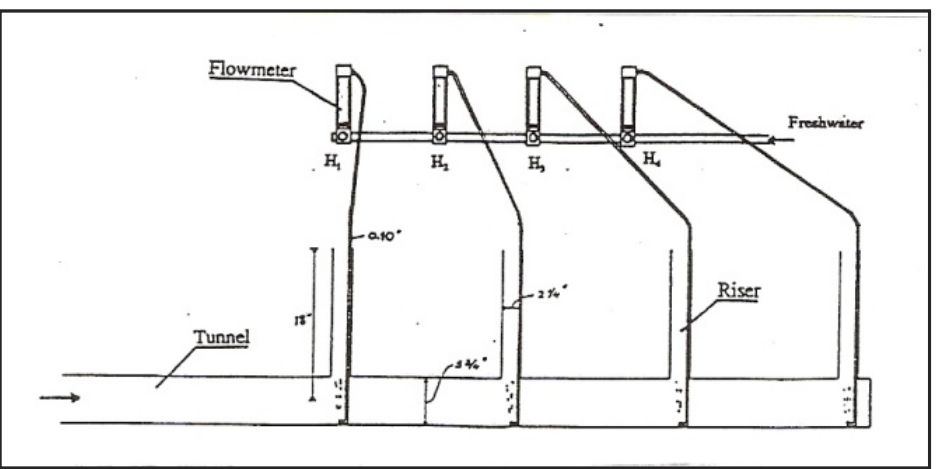

\section{Gambar 4. Skema Percobaan dengan Semprotan Air Berada di bawah Pipa Tegak dalam Pipa Utama.}

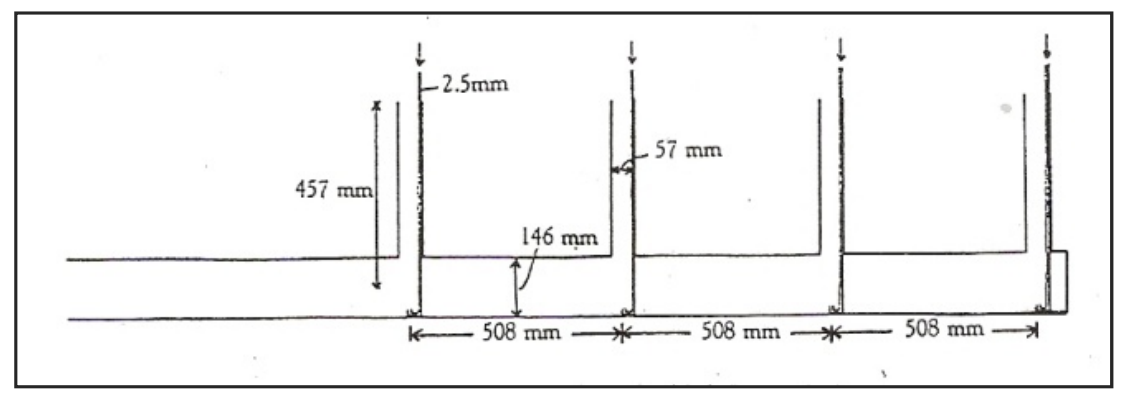

Gambar 5. Semprotan Air Berada di bawah Pipa Tegak

Sepuluh macam percobaan dilakukan untuk mempelajari akibat dari semprotan air. Pertama semprotan air diletakkan hanya di bawah satu pipa, yaitu di bawah pipa tegak pertama, kedua, ketiga dan keempat. Kemudian semprotan diletakkan pada dua pipa tegak yang berurutan, yaitu dengan kombinasi 1 dan 2, 2 dan 3, 3 dan 4. Selain itu, semprotan diletakkan pada tiga pipa tegak yang berurutan dan empat pipa tegak. Setiap semprotan dialirkan air bersih sebesar 1 liter/menit. Kondisi debit diatur melalui 4 buah kran, yaitu $H_{1}, H_{2}, H_{3}$, dan $H_{4}$. Kedalaman air asin dalam tangki air adalah $605 \mathrm{~mm}$.

Percobaan dilakukan pertama kali dengan menyiapkan air asin pada tangki silinder dengan berat jenis $1,010 \mathrm{gram} / \mathrm{cm}^{3}$. Air asin ini dialirkan kedalam tangki air untuk menunjukan bahwa pipa utama (sea-outfall) dipenuhi oleh air asin dan air asin ini masuk ke dalam pipa utama. Kedalaman air asin pada tangki ini adalah $605 \mathrm{~mm}$. Sesudah itu, tangki silinder diisi dengan air bersih dan diberi warna merah. Air bersih yang berwarna merah ini merupakan air kotor yang akan dialirkan ke dalam pipa utama. Jadi dalam hal ini, air kotor seakan-akan dibuang ke laut melalui pipa utama dan keluar bercampur dengan air laut. Semua proses yang terjadi didokumentasikan dengan menggunakan kamera Pentax PC-505.

Percobaan ini dilakukan untuk debit air kotor sebesar 11,36 liter/menit, 28,39 liter/menit, 36,34 liter/menit, 39,75 liter/menit, 54,51 liter/menit dan 68,14 liter/menit, kecuali ketika debit air tawar melalui keempat pipa kecil di bawah pipa tegak, besar debit air kotor adalah 11,36 liter/menit, 28,39 liter/menit, 36,34 liter/menit dan 39,75 liter/menit.

\section{DISKUSI DAN KESIMPULAN}

Kondisi aliran dalam pipa tegak yang ditunjukan pada Tabel 1 untuk semua debit air kotor $\left(Q_{1}=\right.$ 11,36 liter/menit) sampai dengan $Q_{6}=68,14$ liter/menit). Dalam semua kasus, aliran air kotor 
adalah naik. Ini berarti untuk semua debit air kotor yang dialirkan, air kotor selalu mengalir melalui pipa tegak pertama karena adanya tekanan dari air kotor dan perbedaan berat jenis antara air kotor dengan air laut.

Pada Tabel 2 bisa dilihat bahwa ketika debit air kotor $Q_{1}$ sebesar 11,36 liter/menit, air asin masuk ke dalam pipa tegak \#2 untuk percobaan dengan semprotan air berada di bawah pipa tehak \#3, pipa tegak \#4 dan di bawah pipa tegak \#3 dan \#4. Ketika debit air kotor $Q_{1}$ sebesar 11,36 liter/menit dan semprotan air tawar di bawah pipa tegak \#1,2, 1, dan 2, 2 dan 3, 1, 2 dan 3, 2, 3 dan 4, dan semua debit air kotor lebih besar dari 11,36 liter/menit untuk semua percobaan, kondis aliran adalah naik.

Kondisi aliran adalah turun dalam pipa tegak \#3 (lihat Tabel 3) untuk semua debit air kotor sebesar 11,36 liter/menit dan 28,29 liter/menit dalam semua kasus, kecuali untuk percobaan dengan semprotan air terletak di bawah pipa tegak \#1, 2, 3, dan 4. Untuk debit air kotor sebesar 36,34 liter/menit, aliran naik untuk semua percobaan dengan semprotan air di bawah pipa tegak \#3, 1, 2, dan 3, dan 1, 2, 3, dan 4, tetapi untuk yang lainnya adalah turun. Debit air kotor naik untuk aliran sebesar 39,75 liter/menit, kecuali untuk percobaan dengan semprotan air berada di bawah pipa tegak \#4, 1, dan 2, dan 2, 3, dan 4. Aliran air kotor dalam pipa tegak naik untuk debit air kotor sama atau lebih besar daripada 54,51 liter/menit.

Kondisi aliran dalam pipa tegak \#4 ditunjukan pada Tabel 4. Tidak ada intrusi air laut ketika debit air kotor lebih besar atau sama dengan 36,34 liter/menit untuk percobaan dengan semprotan air berada di bawah pipa tegak $\# 1,2,3$, dan 4 . Kondisi ini juga terjadi untuk percobaan dengan semprotan air yang ada di bawah pipa tegak \#4, 3 dan 4, dan 2, 3, dan 4 ketika debit air kotor sama atau lebih besar daripada 54,51 liter/menit. Untuk percobaan lainnya, kondisi aliran adalah turun untuk semua aliran diantara 11,36 liter/menit dan 68,14 liter/menit.

Profil desakan air asin dalam pipa utama untuk percobaan dengan semprotan air berada di bawah pipa tegak ditunjukkan pada Gambar 6 sampai dengan Gambar 15. Profil desakan air asin ini merupakan batas antara air laut dengan air kotor. Pada gambar tersebut juga menunjukan kehadiran semprotan air dalam pipa utama membantu aliran ke atas dalam pipa tegak dan mempunyai keuntungan dalam mengurangi debit pembilasan.

Perubahan pada Tabel 1 sampai dengan Tabel 4 menunjukkan keuntungan dari semprotan berukuran kecil. Aliran naik terjadi pada pipa tegak \#1 untuk semua kondisi. Aliran dalam pipa tegak \#2 umumnya mirip, kecuali untuk percobaan dimana intrusi air laut terjadi. Aliran dalam pipa tegak \#3 umumnya turun pada aliran rendah (kurang dari 36,34 liter/menit), kecuali dalam 2 kasus, dimana semprotan merubah arah dari aliran. Pipa tegak \#4 menunjukkan akibat dari semprotan kecil dalam arah yang jelas. Karena pipa tegak keempat adalah akhir dari pipa utama, ini sangat sulit untuk membilasnya. Dengan tidak adanya semprotan air, insrusi akan terjadi pada semua debit sampai dengan 68,14 liter/menit. Semprotan air tunggal di bawah pipa tegak \#4 diyakini bahwa tidak ada intrusi yang terjadi pada aliran lebih besar dari 39,75 liter/menit. Suatu semprotan di bawah setiap pipa tegak diyakini bahwa semua pipa tegak akan terbilas pada debit lebih besar daripada 36,34 liter/menit.

Hasil yang terbaik terjadi dengan semprotan air berada di bawah setiap pipa tegak. Debit pembilasan adalah kecil untuk semua kondisi ini. Hal ini dibandingkan suatu debit pembilasan sebesar 76,08 liter/menit tanpa semprotan yang dipasang. Semprotan air bagaimanapun menyebabkan penurunan debit sebesar $48 \%$ dalam aliran yang dibutuhkan untuk membilas pipa utama.

Kebanyakan semprotan air di bawah pipa tegak dalam pipa utama hanya memberikan reduksi yang kecil dalam debit pembilasan. Ini adalah lebih kurang 10\%. Pengecualian terjadi ketika semprotan air ketika berada pada semua pipa tegak. Pengurangan debit pembilasan dalam kasus itu adalah berarti. Semprotan air berada pada semua pipa tegak mengurangi debit pembilasan menjadi 36,34 liter/menit (48\%) dibandingkan terhadap tanpa semprotan air $(76,08$ liter/menit) pada beda berat jenis yang sama. Ini adalah kesimpulan yang berarti untuk semua percobaan. 


\section{DAFTAR PUSTAKA}

Adams, E.E., Sahoo, D., Liro, C.R., dan Zhang, X., (1994), Hydraulics of Seawater Purging in Tunneled Wastewater Outfall, Journal of Hydraulic Engineering, Vol. 120, No. 2, 209-226.

Bennet, N.J., (1981), Intial Dilution: A Practical Study on Hastings Long Sea Outfall, Proceedings Institution of Civil Engineers, Part 1, Vo. 70, February, 113-122.

Charlton, J.A., (1982), Salinity Intrusion into Multiport Sea Outfalls, Proceedings $18^{\text {th }}$ International Conference in Coastal Engineering, Capetown, 2376-2385.

Charlton, J.A., (1982), Hydraulic Modelling of Saline Intrusion into Sea Outfalls, Proceedings Internacional Conference on the Hydraulic Modelling of Civil Engineering Structures, Coventry, England, September, 349-356.

Charlton, J.A., Davies, P.A., dan Bethune, G.H.M., (1987), Sea Water Intrusion and Purging in Multiport Sea Outfalls, Proceedings of Multiport Sea Outfalls, Proceedings of Institution of Civil Engineering, Part 2, Vol. 83, March, 263-274.

Munro, D., (1981), Sea Water Exclusion from Tunneled Outfalls Discharging Sewage, Report 7-M, Water Research Centre, Stevenage Laboratory.

Wilkinson, D.L., (1984), Purging of Saline Wedges from Ocean Outfalls, Journal of Hydraulic Engineering, Vol. 110, No. 12, 1815-1829.

Wilkinson, D.L., (1985), Seawater Circulation in Sewage Outfall Tunnels, Journal of Hydraulic Engineering, Vo. 111, No. 5, 846-858.

Wilkinson, D.L., (1998), Hydraulic Modelling of Tunneled Outfalls, Proceedings International Conference on Marine Disposal of Wastewater, Wellington, New Zealand.

Wood, I.R., Bell, R.G., dan Wilkinson, D.L., (1993), Ocean Disposal Wastewater, World Scientific Publishing Co. Pte. Ltd., Singapore.

\section{NOMENKLATUR}

$D \quad$ diameter pipa utama

$F_{\Delta} \quad$ bilangan densimetrik Froude pada lubang

$Q_{p} \quad$ debit pembilasan

$U_{o} \quad$ kecepatan semprotan/ pancaran pada lubang

$d \quad$ diameter semprotan/ pancaran

$f \quad$ faktor gesekan dari pipa utama

$g \quad$ percepatan gravitasi

$\Delta \rho \quad$ beda berat jenis antara air kotor dengan air asin

$\rho \quad$ berat jenis air semprotan/ pancaran

$\rho_{o} \quad$ berat jenis awal dari semprotan/ pancaran

$\Psi \quad$ koefesien gesekan pipa tegak 

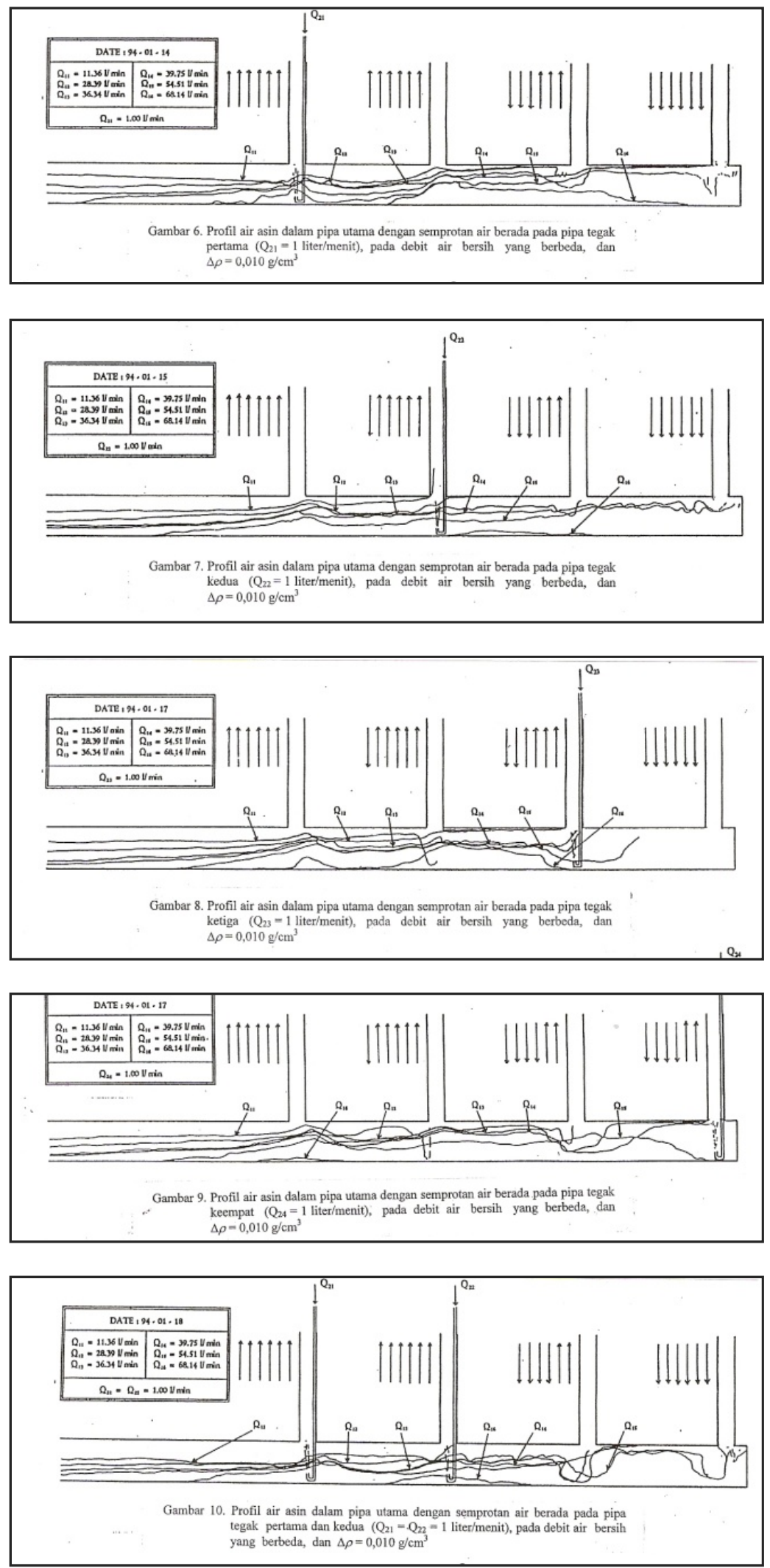

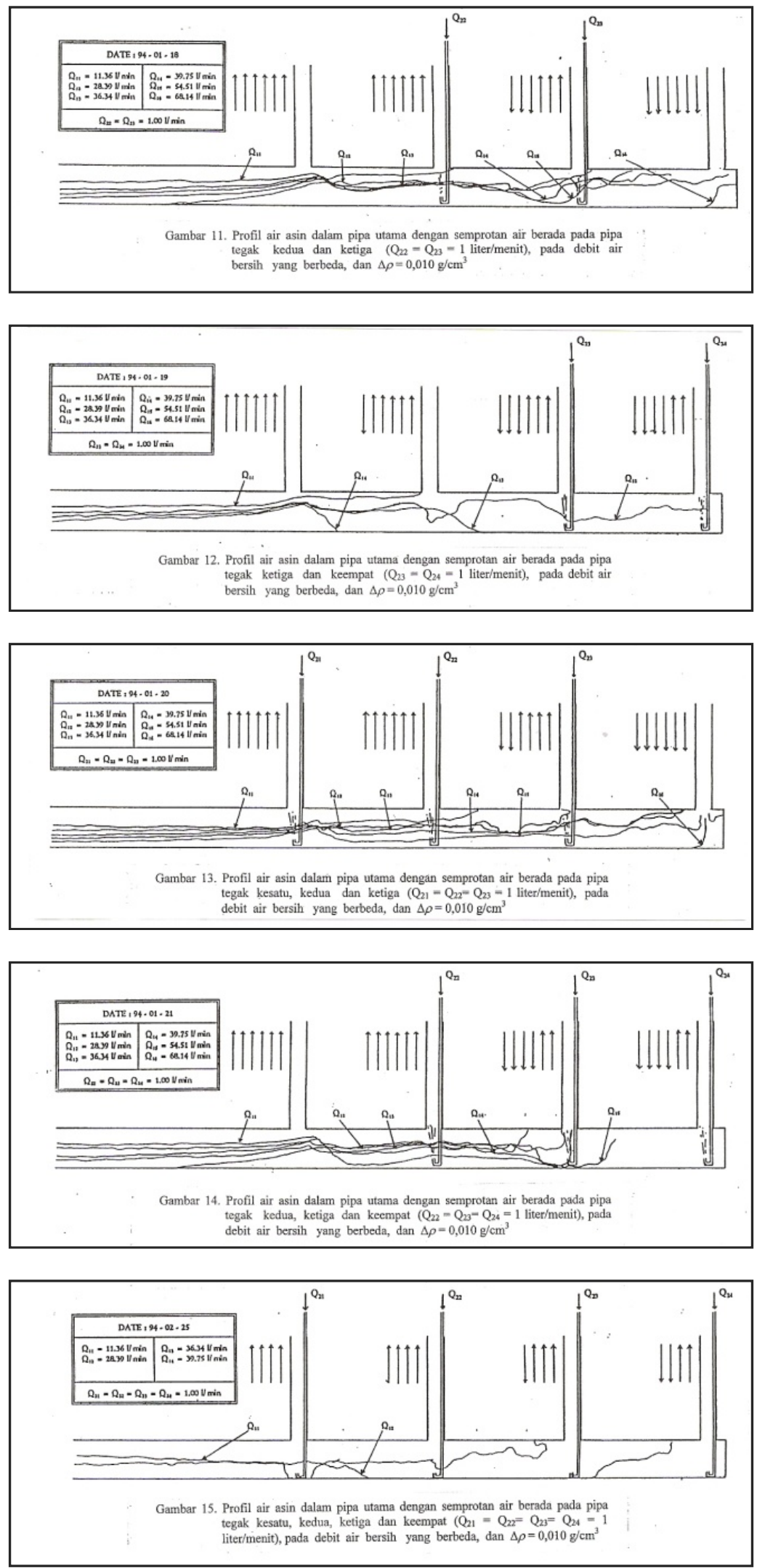


\begin{tabular}{|c|c|c|c|c|c|c|}
\hline \multirow{2}{*}{\begin{tabular}{c|} 
JENIS \\
PERCOBAAN
\end{tabular}} & \multicolumn{6}{|c|}{ KEADAAN ALIRAN DALAM PIPA TEGAK\# 1} \\
\hline & $Q_{1}=11,36 \mathrm{Vmt}$ & $Q_{z}=28,39 \mathrm{Vmt}$ & $Q^{-36}=3.34 \mathrm{Vmt}$ & $Q-39,73 \mathrm{Vmt}$ & $Q-54,51 \mathrm{Vmt}$ & $Q_{0}-68,14 \mathrm{Vmt}$ \\
\hline $\begin{array}{l}\text { Tanpa Semprotan dalam } \\
\text { Pipa Togak } \\
\Delta p=0,010 \mathrm{~g}^{\prime} \mathrm{cm}^{3}\end{array}$ & Keatas & Keatas & Keatas & Keatas & Keatas & Keataz \\
\hline $\begin{array}{l}\text { Semprotan Air } \\
Q=1 \text {. V/mt dibawah } \\
\text { Pipa Tegak } \# 1 \text { 1 } \\
\Delta \rho=0,010 \mathrm{~g} / \mathrm{cm}^{3}\end{array}$ & Keatas & Keatas & Keatas & Keatas & Keatas & Keatas \\
\hline 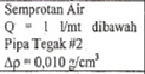 & Keetais & Keatas & Keatas & Keatas & Keatas & Keatas \\
\hline $\begin{array}{l}\text { Semprotan Air } \\
Q=1 \text { Vnat dibawah } \\
\text { Pipa Tegak } \# 3 \\
\Delta \rho=0,010 \mathrm{~g} / \mathrm{cm}^{3}\end{array}$ & Keatas & Keatas & Keatas & Keatas & Keatas & Keatas \\
\hline $\begin{array}{l}\text { Semprotan Air } \\
Q=1 \mathrm{Vmt} \text { dibawah } \\
\text { Pipa Tegak } \# 4 \\
\Delta \rho=0,010 \mathrm{~g} / \mathrm{cm}^{3}\end{array}$ & Keatas & Keatas & Keatas & Keatas & Keatas & Keatas \\
\hline $\begin{array}{l}\text { Semprotan Air } \\
Q=1 \text { Imt dibawah } \\
\text { Pipa Tegak } \# 1 \text { \& } 2 \\
\Delta \rho=0,010 \mathrm{~g} / \mathrm{cm}^{3}\end{array}$ & Keatas & Keatas & Keatas & Keatas & Keatas & Keatas \\
\hline $\begin{array}{l}\text { Semprotan } A \text { ir } \\
Q=11 \text { Vmt dibanah } \\
\text { Pipa Tegak } \# 2 \& 3 \\
\Delta \rho=0,010 \mathrm{~g}^{2} \mathrm{~cm}^{3}\end{array}$ & Keatas & Keatas & Keatas & Keatas & Keatas & Keatas \\
\hline 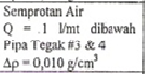 & Keatas & Keatas & Keatas & Keatas & Keatas & Keatas \\
\hline $\begin{array}{l}\text { Semprotan Air } \\
Q=1 \text { Amt dibaswah } \\
\text { Pipsi Tegal } \# 1,2 \& 3 \\
\Delta \rho=0,010 \mathrm{wcm}^{3}\end{array}$ & Kentas & Keatas & Keatas & Keasas & Kentas & Kentas \\
\hline $\begin{array}{l}\text { Semprotan Air } \\
Q=1 \text { Vmt dibawah } \\
\text { Pipa Tegak } \# 2,3 \& 44 \\
\Delta \rho=0,010 \mathrm{~g} / \mathrm{cm}^{3}\end{array}$ & Keatas & Keatas & Keatas & Kentas & Keatas & Keatass \\
\hline 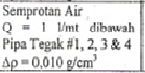 & Keatas & Keatas & Keatas & Kestas & Keatas & Kcatas \\
\hline
\end{tabular}

Tabel 1. Keadaan aliran dalam pipa tegak \# 1 pada debit dan berat jenis yang sama

\begin{tabular}{|c|c|c|c|c|c|c|}
\hline \multirow{2}{*}{$\begin{array}{c}\text { JENIS } \\
\text { PERCOBAAN }\end{array}$} & \multicolumn{6}{|c|}{ KEADAAN ALIRAN DALAM PIPATEGAK\# 3} \\
\hline & $Q_{1}=11,36 \mathrm{Vmt}$ & $\mathrm{Q}_{\mathrm{r}}=28,39 \mathrm{Vmat}$ & $Q_{3}=36,34 \mathrm{Vmt}$ & Q $=39,75 \mathrm{Vmt}$ & G-54,51/mit & $Q_{5}-68,14 / \mathrm{mt}$ \\
\hline $\begin{array}{l}\text { Tanpa Semprotan dalam } \\
\text { Pipa Tegak } \\
\Delta p=0,010 \mathrm{~g}^{\prime} \mathrm{cm}^{3}\end{array}$ & Kebawah & Kebawah & Kebawah & Keatas & Keatas & Keatas \\
\hline $\begin{array}{l}\text { Semprotan Air } \\
Q=1 \quad 1 \text { Vmt dibawah } \\
\text { Pipa Tegak } \# 1 \\
\Delta \rho=0,010 \mathrm{~g}^{\prime} \mathrm{cm}^{3}\end{array}$ & Kebawah & Kebawah & Kebawah & Keatas & Keatas & Keatas \\
\hline $\begin{array}{l}\text { Semprotan Air } \\
Q=1 \text { V/mt dibawah } \\
\text { Pipa Tegak } \# 22 \\
\Delta \rho=0,010 \mathrm{~g}^{3} \mathrm{~cm}^{3}\end{array}$ & Kebavalh & Kebawah & Kebawah & Keatas & Keatas & Keatas \\
\hline $\begin{array}{l}\text { Semprotan Air } \\
Q=1 \text { Vimt dibawah } \\
\text { Pipa Tegak } \# 3 \\
\Delta \rho=0,010 \mathrm{~g} / \mathrm{cm}^{3}\end{array}$ & Kebawah & Kebawah & Keatas & Keatas & Keatas & Keatas \\
\hline $\begin{array}{l}\text { Semprotan Air } \\
Q=1 \text { Vint dibawah } \\
\text { Pipa Tegak } \# 4 \\
\Delta \rho=0,010 \mathrm{~g}^{2} \mathrm{~cm}^{3}\end{array}$ & Kehawah & Kebawah & Kebawah & Kebawah & Keatas & Keatas \\
\hline $\begin{array}{l}\text { Semprotan Air } \\
Q=1 \text { Vimt dibawah } \\
\text { Pipa Tegak } \# 1 \& 2 \\
\Delta \rho=0,010 \mathrm{~g} / \mathrm{cm}^{3}\end{array}$ & Kebawah & Kebawah & Kebawah & Kebawah & Keatas & Keatas \\
\hline $\begin{array}{l}\text { Semprotan Air } \\
Q=11 \text { Vimt dibawah } \\
\text { Pipa Tegak } \# 2 \& 3 \\
\Delta \rho=0,010 \mathrm{~g} / \mathrm{cm}^{3}\end{array}$ & Kebawah & Kebawah & Kebawah & Keatas & Keatas & Keatas \\
\hline $\begin{array}{l}\text { Semprotan Air } \\
Q=1 \text { V/mt dibawah } \\
\text { Pipa Tegak } \# 3 \& 44^{3} \\
\Delta p=0,010 \mathrm{~g} / \mathrm{cm}^{3}\end{array}$ & Kebawah & Kebawah & Kebawah & Keatas & Keatas & Keatas \\
\hline $\begin{array}{l}\text { Semprotan Air } \\
Q=1 \mathrm{Vmt} \text { dibawah } \\
\text { Pipa Tegak } \# 1,2 \& \mathrm{C}^{3} \\
\Delta \rho=0,010 \mathrm{~g}^{3} \mathrm{~cm}^{3}\end{array}$ & Kebawah & Kebawah & Keatas & Keatas & Keatas & Keatas \\
\hline $\begin{array}{l}\text { Semprotan Air } \\
Q=1 \text { Vmt dibawah } \\
P_{i p a} \text { Tegak } \# 2,3 \& 4 \\
\Delta \rho=0,010 \mathrm{~g} / \mathrm{cm}^{3}\end{array}$ & Kebawah & Kebawah & Kebawah & Kebawah & Keatas & Keatas \\
\hline $\begin{array}{l}\text { Semprotan Air } \\
Q=1 \quad 1 \mathrm{Vmt} \text { dibawah } \\
\text { Pipa Tegak } \# 1,2,3 \& 4 \\
\Delta \rho=0,010 \mathrm{~g} / \mathrm{cm}^{3}\end{array}$ & Keatas & Keatas & Keatas & Keatas & Keatas & Keatas \\
\hline
\end{tabular}

Tabel 3. Keadaan aliran dalam pipa tegak \# 3 pada debit dan berat jenis yang sama

\begin{tabular}{|c|c|c|c|c|c|c|}
\hline \multirow{2}{*}{$\begin{array}{c}\text { JENIS } \\
\text { PERCOBAAN } \\
\end{array}$} & \multirow{2}{*}{\multicolumn{6}{|c|}{ KEADAAN ALIRAN DALAM PIPA TEGAK\#2 }} \\
\hline & $Q_{1}=11,36 \mathrm{Vmt}$ & & & & & $Q_{0}=68,14 \mathrm{vmt}$ \\
\hline $\begin{array}{l}\text { Tanpa Semprotan dalam } \\
\text { Pipa Tegak } \\
\Delta \rho=0,010 \mathrm{~g}^{2} \mathrm{~cm}^{3}\end{array}$ & Keatas & Keatas & Keatas & Keatas & Keatas & Keatas \\
\hline $\begin{array}{l}\text { Semprotan Air } \\
Q=1 \text { Vmt dibawah } \\
\text { Pipa Tegak \#1 } \\
\Delta \rho=0,010 \mathrm{gcm}^{3}\end{array}$ & Keatas & Keatas & Keatas & Keatas & Keatas & Keatas \\
\hline $\begin{array}{l}\text { Semprotan Air } \\
Q=11 \mathrm{lmt} \text { dibawah } \\
\text { Pipa Tegak } \# 2 \\
\Delta p=0,010 \mathrm{~g}^{2} \mathrm{~cm}^{3}\end{array}$ & Keatas & Keatas & Keatas & Keatas & Keatas & Keatas \\
\hline $\begin{array}{l}\text { Semprotan Air } \\
Q=1 \mathrm{~V} / \mathrm{mt} \text { dibawah } \\
\text { Pipa Tegak } \# 3 \\
\Delta \rho=0,010 \mathrm{~g}^{\mathrm{cm}} \mathrm{cm}^{3}\end{array}$ & Kebawah & Keatas & Keatas & Keatas & Keatas & Keatas \\
\hline $\begin{array}{l}\text { Semprotan Air } \\
Q=1 \mathrm{~V} / \mathrm{mt} \text { dibawah } \\
\text { Pipa Tegak } \# 4 \\
\Delta \rho=0,010 \mathrm{~g} / \mathrm{cm}^{3}\end{array}$ & Kebawah & Keatas & Keatas & Keatas & Keatas & Keatas \\
\hline $\begin{array}{l}\text { Semprotan Air } \\
0=1 \text { Al/mt dibawah } \\
\text { Pipa Tegak } \# 1 \& 2.2 \\
\Delta \rho=0,010 \mathrm{~g}^{3} \mathrm{~cm}^{3}\end{array}$ & Keatas & Keatas & Keatas & Keatas & Keatas & Keatas \\
\hline $\begin{array}{l}\text { Semprotan Air } \\
Q=1 \text { limt dibawah } \\
\text { Pipa Tegak } \# 2 \& 3 \\
\Delta p=0,010 \mathrm{~g} / \mathrm{cm}^{3}\end{array}$ & Keatas & Keatas & Keatas & Keatas & Keatas & Keatas \\
\hline 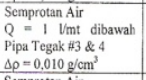 & Kebawah & Keatas & Keatas & Kentas & Keatas & Keatas \\
\hline $\begin{array}{l}\text { Semprotan Air } \\
Q=1 \text { Vint dibawah } \\
\text { Pipa Tegak } \# 1,2 \& 3 \\
\Delta p=0,010 \mathrm{~g}^{3} \mathrm{~cm}^{3}\end{array}$ & Keatas & Keatas & Keatas & Keatas & Keatas & Keatas \\
\hline $\begin{array}{l}\text { Sermprotan Air } \\
Q=1 \text { I/mt dibavah } \\
\text { Pipa Tegakt } \# 2,3 \& \& 4 \\
\Delta \rho=0,010 \mathrm{~g} / \mathrm{cm}^{3}\end{array}$ & Kcatas & Keatas & Keatas & Keatas & Keatas & Keatas \\
\hline $\begin{array}{l}\text { Semprotan Air } \\
Q=11 \text { 1/mt dibawah } \\
\text { Pipa Tegan } \# 1,2,3 \& 4 \\
\Delta \rho=0,010 \mathrm{~g} \mathrm{~cm}^{3}\end{array}$ & Keatas & Keatas & Keatas & Keatas & Keatas & Keatas \\
\hline
\end{tabular}

Tabel 2. Keadaan aliran dalam pipa tegak $\# 2$ pada debit dan berat jenis yang sama

\begin{tabular}{|c|c|c|c|c|c|c|}
\hline \multirow{2}{*}{$\begin{array}{c}\text { JENIS } \\
\text { PERCOBAAN }\end{array}$} & \multicolumn{6}{|c|}{ KEADAAN.ALIRAN DALAM PIPA TEGAK\# 4} \\
\hline & $Q_{1}=11,36 / \mathrm{mt}$ & $Q_{2}=28,39 \mathrm{Vmt}$ & $Q=36,34 / / m t$ & $Q=39,75 \mathrm{Vmt}$ & $Q=54,51 \mathrm{lmt}$ & $Q_{0}=68,14 \mathrm{Vmt}$ \\
\hline $\begin{array}{l}\text { Tanpa Semprotan dalam } \\
\text { Pipa Tegak } \\
\Delta \rho=0,010 \mathrm{~g} \mathrm{~cm}^{3}\end{array}$ & Kebawah & Kebawah & Kebawah & Kebawah & Kebawah & Kebawah \\
\hline $\begin{array}{l}\text { Semprotan Air } \\
Q=1 \text { I Vmt dibawah } \\
\text { Pipa Tegak } \# 1 \\
\Delta \rho=0,010 \mathrm{~g} / \mathrm{cm}^{3}\end{array}$ & Kebawah & Kebawah & Kebawah & Kebavah & Kebawah & Kebawah \\
\hline $\begin{array}{l}\text { Semprotan Air } \\
Q=1 \text { V V/mt dibawah } \\
\text { Pipa Tegak } \# 2 \\
\Delta \rho=0,010 \mathrm{~g} / \mathrm{cm}^{3}\end{array}$ & Kebawah & Kebawaht & Kebawah & Kebawah & Kebawah & Kebawah \\
\hline $\begin{array}{l}\text { Semprotan Air } \\
Q=1 \mathrm{~V} / \mathrm{mt} \text { dibawh } \\
\text { Pipa Tegak } \# 3 \\
\Delta \rho=0,010 \mathrm{~g} / \mathrm{cm}^{3}\end{array}$ & Kebawah & Kebawah & Kebawah & Kebawah & Kebawah & Kebawah \\
\hline $\begin{array}{l}\text { Semprotan Air } \\
Q=1 \text { V/mt dibawah } \\
\text { Pipa Tegak } \# 44 \\
\Delta \rho=0,010 \mathrm{~g} / \mathrm{cm}^{3}\end{array}$ & Kebawah & Kebawah & Kebawah & Kebawah & Keatas & Keatas \\
\hline $\begin{array}{l}\text { Semprotan Air } \\
Q=1 \mathrm{Vmt} \text { dibawah } \\
\text { Pipa Tegak } \# 1 \& 2 \\
\Delta \rho=0,010 \mathrm{~g} / \mathrm{cm}^{3}\end{array}$ & Kebawah & Kebavah & Kebawah & Kebawah & Kebawah & Kebawah \\
\hline $\begin{array}{l}\text { Semprotan Air } \\
Q=1 \text { Imt dibawah } \\
\text { Pipa Tegak } \# 2 \& 3 \\
\Delta \rho=0,010 \mathrm{~g} / \mathrm{cm}^{3}\end{array}$ & Kebawah & Kebawah & Kebawah & Kebawah & Kebawah & Kebavah \\
\hline $\begin{array}{l}\text { Semprotan Air } \\
Q=1 \text { I Vmt dibawah } \\
\text { Pipa Tegak } \# 3 \& 44 \\
\Delta p=0,010 \mathrm{~g}^{2} \mathrm{~cm}^{3}\end{array}$ & Kebawah & Kebawah & Kebawah & Kebawah & Keatas & Keatas \\
\hline $\begin{array}{l}\text { Semprotan Air } \\
Q=1 \text { Vimt dibawah } \\
\text { Pipa Tegak } \# 1,2 \& 3 \\
\Delta \rho=0,010 \mathrm{~g} / \mathrm{cm}^{3}\end{array}$ & Kehawah & Kebawah & Kebawalt & Kebawah & Kebawalh & Kebawah \\
\hline $\begin{array}{l}\text { Semprotan Air } \\
Q=1 \text { I/mt dibawah } \\
\text { Pipa Tegak } \# 2,3 \& 4 \\
\Delta \rho=0,010 \mathrm{~g}^{2} \mathrm{~cm}^{3}\end{array}$ & Kebawaht & Kebawalt & Kebawah & Kehawah & Keatas & Keatas \\
\hline $\begin{array}{l}\text { Semprotan Air } \\
Q=1 \mathrm{~V} / \mathrm{Vt} \text { dibawah } \\
\text { Pipa Tegat } \mathrm{Tl} 1,2,3 \& 4 \\
\Delta p=0,010 \mathrm{~g} / \mathrm{cm}^{3}\end{array}$ & Kebawaht & Kebawah & Keatas & Keatas & Keata, & Keatas \\
\hline
\end{tabular}

Tabel 4. Keadaan aliran dalam pipa tegak \# 4 pada debit dan berat jenis yang sama 